\title{
GENERAL COMMERCIAL TERMS AND STANDARD-FORM CONTRACTS IN INTERNATIONAL BUSINESS RELATIONS
}

\author{
Michal Malacka \\ Palacky University in Olomouc, Faculty of Law
}

\begin{abstract}
The present paper discusses the importance of general commercial terms and business conditions as basis for the conclusion of commercial contracts. The paper describes the historical development of general commercial terms and the increasing importance of individually stipulated standard-form contracts as well as the influence of both legal sources on the contract practice in international trade. The notion "general commercial terms" (abbr. GCT) designates proposals for standard contracts as produced in many cases by neutral experts of national and international organizations, whereas the notions "terms of business" or "general terms of business" refer to standardform contracts which one party to a contract or both submit and which are accepted by the parties as basis of their negotiations. Subsequently, the advantages and disadvantages associated with the use of general commercial terms on the one hand, and individually negotiated terms of business on the other will be identified. The paper also distinguishes general contract conditions according to their types and formations, both from the point of view of international law and with regard to Czech statute law, as it is established mainly in the Civil Code. However, this paper does not only present the legal issues affiliated with the employment of general commercial terms and "parties' terms of business", it also focuses on the economic aspects of the use of established contract forms and conditions. Likewise, the paper is working out the areas where general commercial terms are applied in international trade and it points at important international organizations that work with, or contribute to, general commercial terms, such as the International Chamber of Commerce (ICC), the Institute for the Unification of Private Law (UNIDROIT), and the United Nations Commission on International Trade Law (UNCITRAL) etc. Thus, the work shall demonstrate the importance and indispensability of general contract terms and individually submitted and negotiated terms of business in the trade of goods, whether international or national.
\end{abstract}

Keywords: General commercial terms (GCT), (general) terms of business, nature of business conditions, standard form contracts, unification of the laws in international trade, international business, indirect contractual stipulation, direct contractual stipulation, interpretation rules, different contractual arrangements, international sales contract.

\section{INTRODUCTION}

The use of general commercial terms and pre-formulated business conditions facilitates the conclusion of contracts. The entire content of the contract need not be renegotiated in every particular case as previous consent is enough, if both parties agree on those parts of the contract concerning their mutual rights and duties which are proposed by appropriate general commercial terms or standardform contracts. This process is economically important since it creates standardized settlements 
which are characteristic for the business sector worldwide. Reference to general commercial terms in contracts does not mean that the contracting parties may not include additional provisions which they do not want to give up. By adjustment of individual contracts in reference to general commercial terms or business conditions of the parties, the risk connected with misconceptions and disputes that may be induced by the contract is lower. General commercial terms often make the provisions of law less ambiguous and more precise or eventually regulate questions, which are not considered or not regulated by the parties, or only marginally regulated by statute law.

In the field of international trade the parties to a commercial contract cannot be expected to specifically negotiate all the complex terms of such a contract. Such conduct should not be envisaged as the regular proceeding in international business; rather the parties should use terms and clauses which are already well accepted and offered to contracting businessmen in different forms. ${ }^{1}$ Nevertheless, it cannot be neglected that the use of general commercial terms provides not only advantages, but disadvantages for either of the contracting parties as well. Among the most important advantages we may sort out the strengthening of the legal and economic securities of the parties in connection with the choice of the applicable law, the rationalization and acceleration of the contractual process. The express agreements of the parties should be limited to supplementary stipulations only, if other rights and obligations are well adjusted in the general commercial terms to which the parties refer. If the same parties repeatedly conclude contracts of identical or similar content they may identify the most frequently occurring risks and problems and counteract by incorporating a suitable set of covenants. From this point of view, the general commercial terms, in fact, make the contractual process less expensive and save the time of the parties. Within the range of party autonomy it is possible to deviate from the content of statutory provisions whenever the legal adjustment would not deal with all the answers which could be in the interest of the parties. The precise definition of the rights and obligations of the parties may ultimately minimize the risk of the dispute and save procedural costs. It is also important to realize that conducting litigation abroad may be lengthy, costly, and often unpredictable as to its outcome.

One of the disadvantages that are frequently connected with the use of general commercial terms and pre-formulated terms of business is the restriction of contractual freedom, which is generated by the one party to the contract refusing to allow the modification of her/his business terms, while the same party is holding a stronger economic position than the other. Such a situation will leave to the other party only one choice, either to conclude the contract, or to abstain thereof. Thus, the generalization resulting from the use of standard terms for all the contracts concerning identical or very similar performances may have a detrimental effect for the weaker of the contracting parties, whenever it would be more proper to negotiate the contract in regard of its particular performance and content. In practice, each party to the contract is trying to enforce the terms and conditions which are incorporated in the standard contract forms which the party is using as a basis for contracts, and to reject the proposed contract terms of the other party. This scenario often appears as the so-called "battle of forms", which means that each of the contracting parties resorts to the own business conditions, notwithstanding their divergent content. Or, one party sends a proposition of the contract to the other thereby referring to the terms as included in her/his standard form, the other accepts the offer and encloses her/his own terms of business which provide diverging clauses. In the end the crucial question is, whether and on which basis an agreement has been reached. This situation is undesirable and a better approach would be a consultation of individual points of the

1 RAMBERG, J.: International commercial transactions. Stockholm: Kluwer Law International, 1998, p. 17. 
general commercial terms conditions and a search for the interpretation of the parties' statements that is more suitable for both parties and would render a compromise possible. ${ }^{2}$

With regard to national as well as international business contracts, it must not be neglected, that standard form contracts are usually used by contracting parties of a certain dimension, not by small traders or by consumers. Usually the legally and economically stronger party to a contract is in the position to enforce the contract in accordance with the own favourable conditions of business. In international trade many general commercial terms suggest the use of model contract clauses which would guarantee a neutral treatment of the interest of both commercial parties. For contracts between businesspersons and consumers protective measures in favour of the latter are stated in national consumer laws implementing the relevant EU-Directives. ${ }^{3}$

In connection with the disadvantages it should be mentioned at this point, that in international business there cannot be provided the same protection for businessmen as is granted to the consumers in consumer contracts. Dangers stemming from the fact that in commercial contracts both parties are businesspersons are somehow mitigated by the use of standardized proposals of general commercial terms elaborated by international organizations; however, some risks and a certain platform of difficulties still remain. ${ }^{4}$

The main functions of internationally unified general commercial terms include, in particular, ${ }^{5}$ the rationalization of contract negotiations. Parties can prepare and clarify at an early time already some complicated questions, which could prolong the negotiation of the contract. They can also have a positive psychological influence which may contribute to the elimination of stress in the formation of the contract and may have a positive impact for future developments and negotiations with the foreign partner. The use of general terms and conditions may be helpful in overcoming the differences between the legal systems involved by finding solutions which are acceptable for businesspersons from different countries, with different legal systems and dissimilar economic stages of development. circumstances. Indeed, the idea of unification of the rules of international trade and commerce is strongly promoted by the international and supranational institutions offering model contracts on the European and global scale.

\section{HISTORICAL CONCEPT AND ESTABLISHMENT OF GENERAL COMMERCIAL TERMS}

From the historical point of view, the general terms and conditions and their successful establishment relate to the interest for the most profitable approach to the realisation of the high number of

2 SCHMITTHOFF, C.: Schmitthoff's export trade. The law and practice of international trade. London: STEVENS \& SONS, 1986, p. 83.

3 Former Council Directive 85/577/EEC of 20 December 1985 to protect the consumer in respect of contracts negotiated away from business premises; former Directive 97/7/EC of the European Parliament and of the Council of 20 May 1997 on the protection of consumers in respect of distance contracts. Replaced by Directive 2011/83/EU of the European Parliament and of the Council of 25 October 2011 on consumer rights, amending Council Directive 93/13/EEC and Directive 1999/44/EC of the European Parliament and of the Council and repealing Council Directive 85/577/EEC and Directive 97/7/EC of the European Parliament and of the Council, O.J. 2011, L 304/64.

4 ROZEHNALOVÁ, N.: Standardizované formy uzavírání obchodních smluv v mezinárodním obchodè. Brno : Masarykova Univerzita, 1991, p. 33.

5 ROZEHNALOVÁ, N.: Právo mezinárodního obchodu. $2^{\text {nd }}$ Edition. Praha : ASPI, 2006, p. 235. 
contractual relations in the commercial business. Modern history clearly shows that general commercial terms developed and found an increasingly widespread application in the context of the industrial revolution with its industrialized mass production requesting conformable contracts. ${ }^{6}$ Despite the many references in the Anglo-American literature on the law of commercial contracts in this time, ${ }^{7}$ general commercial terms were used already much earlier. ${ }^{8}$ There is evidence of their use in ancient Roman law. ${ }^{9}$ Landlords were the first among the businessmen of that time who resorted to unilaterally advantageous clauses in their contractual arrangements. ${ }^{10}$ Further development proceeded in connection with the medieval evolution of Private International Law as a result of the impressive development of the law of international trade in the legal systems of the northern Italian cities from the $12^{\text {th }}$ to the $15^{\text {th }}$ centuries. ${ }^{11}$

In the context of early border-crossing contracts general commercial terms mainly concerned contracts of transport, whether by land or sea. In particular, maritime trade was significantly more dangerous than it is today. ${ }^{12}$ The amount or level of risk also corresponded to the necessary insurance of the transported goods, eventually, a loss of valuable cargo. Similarly, insurance contracts became soon standardized, and new model contracts were formulated, which were recognized by the judicial institutions of the concerned states. ${ }^{13}$ Thus, the maritime insurance industry was strongly expanding in the $16^{\text {th }}$ century and, as a result of the economic power of the Hanseatic cities, standardized contracts became an acknowledged tool in trade and commerce in Northern Europe as well. However, the true appearance of the mass use of general commercial terms was a reaction to the Industrial Revolution. ${ }^{14}$ Not only the transport sector benefited from the technological progress as it had to comply with the demands for the most flexible, economical, and least time-consuming means of transporting. The break-through of steam-powered railways and their undoubted benefits for business and trade accelerated the use of general commercial terms. This development continued with the increasing haulage of goods by steam liners and trucks driven by combustion-engines and the entry of air transport and shipping, thereby expanding the scope of border-crossing business relations. Over the centuries, the content of general commercial terms has been gradually changing and has switched from the questions concerning the insurance of the transport of goods to other aspects which became standardized and have led to the creation of general commercial terms for the delivery of goods to the final consumer.

It was not only the technological progress, that played a significant role in the development of general commercial terms, rather, that striking development was attributable to a change in legal

6 ROZEHNALOVÁ, N.: Standardizované formy uzavírání smluv v mezinárodním obchodě. Brno: Masarykova Univerzita, 1991, p. 14.

7 SCHMITTHOFF, C.: Schmitthoff's export trade. The law and practice of international trade. London: STEVENS \& SONS, 1986, p. 62.

8 Compare with WESTERMANN, H. P. (ed.): Bürgerliches Gesetzbuch: Handkommentar, Band 1. 13. Edition. Köln: Verlag Dr. Otto Schmidt, 2011, commentary to $\$ 305$.

9 HELLWEGE, Ph.: Allgemeine Geschäftsbedinyungen, einseitig gestellte Vertragsbedingungen und die allgemeine Rechtsgeschäftslehre. Tübingen: Mohr Siebeck, 2010, p. 2.

10 FRIER, B. W.: Landlords, and Tenants in Imperial Rome. New Jersey: Princeton University Press, 1980, p. 63.

11 CORDES, A.: Gut behütet über die Weltmeere. In: Frankfurter Allgemeine Sonntagszeitung, 19. 06. 2011, p. 44., ZIMMERMANN, M.: Mezinárodní právo soukromé. Brno: Cs A.S. Právník, 1933, p. 38.

12 Currently it is necessary to mention problematics of piracy and dangers on sea connected with it, more on Commercial Crime Services. IMB Piracy \& Armed Robbery Map 2017, 2017. Available at : <https://www.icc-ccs.org/piracy-reporting-centre/live-piracy-map> (accessed on 5th November 2018).

13 RANIERI F.: Europäisches Obligationenrecht. 3. Edition Wien: Springer, 2009, pp 30-31.

14 Ibid. 
conditions as well. ${ }^{15}$ This change was attributable to the evolution of free trade and the occurrence of a plurality of national judicial systems on the global market which requested a harmonization of the rules of trade law to which the acting participants of international trade might adhere world-wide.

In the early period of industrialization, in the middle of the $19^{\text {th }}$ century, the development of the law of general commercial terms has been influenced by large professional associations that were creating models of contracts to be applied by the businesspersons of a specific sector of the economy. These non-governmental associations included, for example, the "Waren-Verein der Hamburger Börse e.V.", the London Corn Trade Association which exists until today under the name "Grain and Feed Trade Association". "... In that time all the businesses with a type of goods such as wheat, feed, coffee, rubber, sugar which were transported across the seas have been fully controlled by the forms. In the business with other products such as wood, meat, leather, grease, tea it was not used so universal as in the previous group, however, it was showing tendencies to a boom." ${ }^{16}$ Indeed, the number of other associations whose members were dealing on the basis of their own general terms and conditions became more numerous since that time. For example: The British Wool Confederation; the Cocoa Association of London Ltd; the Federation of Oilseeds and Fats Associations; the International Wool Textile Organization; the Liverpool Cotton Association, the International Federation of Consulting Engineers (FIDIC), The European Engineering Industries Association (Orgalime), and others. ${ }^{17}$

The content of the general commercial terms as proposed by these organizations was repeatedly modified as time passed by. On the one hand, the content had to be adapted to all the questions, which according to experience were becoming the subject of contractual negotiations, that is the way, time and place of loading of the goods, payment conditions, force majeure, passing of risk, et cetera. The need for workable contractual arrangements in practice, and of course the content was shaped by the different positions of the contracting parties in respect of their legal and economic power and, last but not least, by the actual economic situation.

The preparation of model contracts and the use of general commercial terms and conditions quickly developed and, as noted above, the attention has above all been paid to overseas transport. Gradually, the standard form contracts underwent changes not only in respect of their content and quality standards, but also in the persons that compiled them. In the beginning, it was the individual businessman who created the business conditions of his enterprise, but, over the time, the trade unions also took an active part in the process. Two of the aforementioned associations, viz the "WarenVerein der Hamburger Börse" and the London Corn Trade Association became supplemented, for example, by the Silk Association of America and the "Bremer Baumwollbörse", which created anew the whole collection of the business terms and conditions employed in their branch. ${ }^{18}$

In the legal regulation of relations in international trade, the so-called unification of the laws has been also playing an increasingly important role, which may be understood as a targeted global or regional integration activity of the sovereign states on an intergovernmental level. At the beginning of the evolution of general commercial terms the international unification as a whole did not attract

15 Compare major changes with the Council Directive 93/13/EHS from 5. 4. 1993 about unfair terms in the consumer contracts.

16 ROZEHNALOVÁ, N.: Standardizované formy uzavírání obchodních smluv v mezinárodním obchodě. Brno : Masarykova univerzita, 1991, p. 15.

17 Cf. SCHMITTHOFF, C.: Schmitthoff's export trade. The law and practice of international trade. London: STEVENS \& SONS, 1990 pp. 63 seq.

18 In detail available at: <https://baumwollboerse.de/informationen/download/> (accessed on $5^{\text {th }}$ November 2018). 
much attention. At the beginning of the $20^{\text {th }}$ century, when the use of general terms and conditions became more important in international business in general, unification of general commercial terms was rather deemed unnecessary, probably due to its small reach and the extreme nationalism of that time. The importance of the unification process became gradually acknowledged in the early sixties of the $20^{\text {th }}$ century in connection with the steep rise of the European integration process.

Currently, it is hard to imagine that international business relations and the business environment could function without general commercial terms. A statement in the introduction to a contract that would refer to such terms will satisfy both the professional public and the business sector. Reality, theory, and case-law represent other lines, which are a crossing path in the environment of international business and in the separate levels of their collisions. These aspects create the need of finding answers to questions connected with the enforceability and sustainability of specific clauses in general commercial terms in front of the national courts. At the time, the absence of a system of supervision and interpretation by an international court of justice endanger the protective aspects in international business relations. The importance of general commercial terms is, of course, connected with the rise of international business, bound to the intensity of globalization of the world trade and to the demands of the highest degree of simplicity and standardization within the framework of international trade.

Associated with general commercial terms and the problems of their application are the assessment of their implementation and their incorporation into the contract; viz an economic view of the use of general commercial terms, a legally defined approach to their incorporation into the contract, a connection with the system of the Law of conflict of laws, and the choice of the law which is more favourable to the use of general commercial terms et cetera.

General commercial terms in Private International Law, and thus, in international business are undoubtedly related to the competition of individual legal systems in cases, where a choice of law is available for the contracting parties. Also the "competition" of legal systems and as a consequence thereof the existence of a "battle of promotional materials" may have a perceptible influence on the choice of the applicable law. The Law Society of England and Wales came up in 2001 with promotional materials where they have asserted that England and Wales were jurisdictions worth of the choice. ${ }^{19}$ That document was supplemented by the introduction of the Lord Chancellor who proudly reported that people are coming to carry out their businesses in this country because they offer a flexible and reliable legal system. The emphasis was mainly on the economic focus of English law. ${ }^{20} \mathrm{~A}$ first response from abroad was promptly published when the German Lawyers Association issued in 2008 a publication titled "Law made in Germany" 21 and in this promotional material German lawyers emphasize that German law is clear, reliable, systematic and leading to legal certainty. ${ }^{22}$

It is not appropriate to underestimate the ignorance of the law as well as the lack of knowledge of the national legal environment of foreign states. The competition and, in some cases, the export of foreign legal principles or methods may greatly affect real economic issues related to the business

19 The Law Society of England and Wales. England and Wales: The jurisdiction of choice, 2007. Available at: <http://www. eversheds-sutherland.com/documents/LawSocietyEnglandAndWales)urisdictionOfChoice.pdf $>$ (accessed on $5^{\text {th }}$ November 2018)

20 The fact that the judge-made English Common Law and the codified Civil Law in Continental Europe are in many aspects fundamentally different, may have had an underestimated influence on the BREXIT-referendum.

21 Bundesnotarkammer, Bundesrechtsanwaltskammer U.A. Law - Made in Germany, 2012. Available at : <http://www. lawmadeingermany.de/Law-Made_in_Germany.pdf $>$ (accessed on $5^{\text {th }}$ November 2018).

22 Ibid., p. 6. 
and legal environment in the concerned countries. General commercial terms play an important role in the competition of the legal systems as well as in the international advocacy.

National legal systems adhere to different levels of intensity in the control of general commercial terms which are implemented through the general terms and conditions of the national law, that is, by the set of legal rules regulating the procedure of incorporation of general commercial terms into the contract, their implementation, the content of the control of this process, aspects connected with the ineffectiveness and the process of filling up the gaps resulting from the ineffectiveness of these general terms and conditions. The autonomy of the parties' will allow businessmen to escape from the strict regulations and to resort to more favourable legal systems. The contracting parties may also consider their right to choose the law that should apply to their contract in accordance with the unified legal rules of Private International Law as provided in the EU by the "Rome I-Regulation". ${ }^{23}$ In the same way, the provisions of autonomous national conflict law of the concerned national legal systems have to be considered.

Apart from the difficult task to single out the most favourable legal solution for the participants in border-crossing business activities and the strictest legal order as well, it is also very difficult to describe the process of integrating the general commercial terms, the associated control of the process and the implications of the application of the relevant legal provisions. Meanwhile, according to some recent studies, popularity of some particular legal orders is declining ${ }^{24}$ whereas other legal systems are getting more and more thereof..$^{25}$ However, as has already been outlined above, the issue is also related to international unified legislation, ${ }^{26}$ in particular to the UN-Convention on Contracts for the International Sale of Goods.

In respect of the European systems of private law it is obvious that general commercial terms constitute a significant part of the business relation " $\mathrm{B} 2 \mathrm{~B}$ "27 and, according to some opinions, have even taken the place of business customs. ${ }^{28}$

What is the reason for this undisputed position? At this point, we have to consider an economic concept of general commercial terms where entrepreneurs who standardize their contractual terms not only save much time but also the cost associated with the precise drafting of a complex contract. ${ }^{29}$ The current economic situation almost enforces the selection and use of general commercial terms. ${ }^{30}$ With the help of their use, it is to some degree guaranteed that the will of the businessperson will be properly communicated by her/his representatives. ${ }^{31}$ Additionally, the future potential

23 MALACKA, M.: Kolizní metoda v kontextu globalizace a europeizace, Kodifikace obecné části kolizního práva - cesta či omyl? In: Acta Universitatis Brunensis Iuridica, vol. 548, 2016.

24 Cf. for example WESTPHALEN, F. Graf von: Wider die angebliche Unattraktivität des AGB-Rechts. In: Betriebs Berater, 2011, p. 195; JAHN, J.: Zerstörte Vertragsfreiheit!? In: Frankfurter Allgemeine Zeitung, 7. 2. 2012, p. 9; EWER, W.: Unternehmen unter Kontrolle. In: Frankfurter Allgemeine Zeitung, 18. 01. 2012, p. 19.

25 Management Circle. Schweizer Recht im Anlagenbau, 2017 Available at: <http://www.managementcircle.de/seminar/ schweizer-recht-im-anlagenbau.html > (accessed on 5th November 2018)

26 STOFFELS, M.: AGB-Recht. 2. Edition. München: C. H. Beck, 2009, p. 25 and following.

27 MERZ, H.: Massenvertrag und allgemeine Geschäftsbedingungen. In: Festgabe für Wilhelm Schönenberger zum 70. Geburtstag am 21. September 1968. Freiburg: Universität Freiburg, 1968, p. 137.

28 MÜLLER, W. - GRIEBELER, C. - PFEIL, J.: Für eine maßvolle AGB-Kontrolle im unternehmerischen Geschäftsverkehr. In: Betriebs Berater, 2009, p. 2658-2665.

29 ADAMS, M.: Ökonomische Begründung des AGB-Gesetzes. In: Betriebs Berater, 1989, p. 781-788.

30 KRAMER, E.: Art. 19-22 OR. Allgemeine Bestimmungen. Inhalt des Vertrages. Berner Kommentar. Bern: Stämpfli, 1991. $282 \mathrm{p}$.

31 DiMATTEO, L. - JANSEN, A. - MAGNUS, U. - SCHULZE, R.: International Sales Law. Baden - Baden: Nomos, 2016 , p. 51-53. 
risks in the process are reduced to a minimum when the general commercial terms apply. ${ }^{32}$ General commercial terms find their application also in matters that are not adequately addressed by statute law. Whether by filling gaps in statutes or international conventions or by "easing the burden" of the non-mandatory law, it can be confirmed that, in general, business terms and conditions facilitate negotiations between the parties of an intended contract.

The aforementioned aspects, whether legal or economic, are, from an objective point of view, altogether valuable features. It is true, however, that the application of general commercial terms also reflects subjective aspects that are questionable with regard to the controlling function of the terms whether on a national or international level.

Users of general commercial terms are therefore unilaterally determining the content of the contract in a manner which is consistent with their business intentions. It is necessary to draw the attention to the fact that the user and translator of general commercial terms attempts to transfer to the contractual partner, as much as possible, the risk, which is associated with the implementation of the contractual relationship. ${ }^{33}$ This advantage is particularly questionable in view of the fact that avoidance of the danger of an inappropriate transfer of the risk is the fundamental goal of legal and judicial control of general commercial terms. ${ }^{34}$

Together with the common provisions of general commercial terms also clauses which are connected to value issues determine the content of contracts in contemporary international business without being directly connected with the contract and which have not been stated at all in the general commercial terms. Thus, the contract quite often is only a short document that contains only essential elements of the agreement and leaves all other stipulated rights and obligations to the implemented general commercial terms.

The use of general commercial terms in the formation of contracts is, of course, a demanding issue, corrected not only by the provisions of the applicable law but also by the aforementioned perspective, on the basis of which the incorporation and implementation of the general commercial terms are assessed. Economic aspects and the legal environment have already been mentioned as corresponding to the models of the two most important approaches to the control of general commercial terms, namely the legal economic and the contractual theoretical approach. Both approaches are intertwined with the levels of private autonomy as the fundamental principle of the concerned legal orders. Another level consists in respect of possible conflicts of general commercial terms and private autonomy, where contractual theoretical as well as legal and economic perspectives of this issue may also be seen as different ways of finding a solution to these conflicts. The third fundamental path of solving this problem is through the "control of the content" of general commercial terms. ${ }^{35}$

32 BAUER, W. B.: Der Schutz vor unbilligen Allgemeinen Geschäftsbedingungen (AGB) im schweizerischen Recht (Schweizer Schriften zum Handels- und Wirtschaftsrecht). Zürich: Schulthess, 1977.

33 DiMATTEO, L. - JANSEN, A. - MAGNUS, U. - SCHULZE, R.: International Sales Law. Baden - Baden: Nomos, 2016, p. 51-53.

34 BAUDENBACHER, C.: Ansätze zu einer AGB-Kontrolle im schweizerischen Recht. St. Gallen: Wissenschaftlicher Verlag, 1991, p. 17.

35 Cf. SCHÄFER, H.-B. - OTT, C.: Lehrbuch der ökonomischen Analyse des Zivilrechts. 5. Edition. Berlin: Springer, 2012, p. 423-432; BAUDENBACHER, C.: Ansätze zu einer AGBKontrolle im schweizerischen Recht. St. Gallen: Wissenschaftlicher Verlag, 1991, s. 17. 


\subsection{General commercial terms and Their Concept in International Trade}

In practice, direct contractual stipulations of the parties to the contract are included into the contract in order to determine reciprocal rights and obligations. ${ }^{36}$ In the case of a written contract the content of such directly agreed terms shall result from the wording of the agreement or from the proposal for the conclusion of the contract which the other contract party accepts.

Other categories of contractual agreement are the indirect contractual stipulations which can be characterized as certain rules, which determine reciprocal rights and obligations of the parties without being expressly put into words in the contract. Thus, the fact that the reciprocal rights and obligations are determined thereby follows from the parties' intention to be bound. An indirect contractual stipulation is not an explicit legal provision. It appears therefrom that the content of the legal relationship may also be determined by other contractual clauses referring in particular to the terms of trade, business practices, internationally recognized clauses governed by the rules on unloading ${ }^{37}$ and on other activities connected with the contract. The application of business custom is allowed by international law in international business and by domestic law in respect of domestic trade. ${ }^{38}$

We distinguish business custom of trade from customary law, which is defined as a spontaneous rule of conduct, generally observed with the knowledge that it is a rule of law to be accepted. To become a legitimate source of customary law (or "legal custom") it has to represent the opinio neccessitatis or conviction of the necessity to use the rule, and also usus longaevus, viz the unchanged observance of the rule in practice over a long period of time. Legal custom is applicable in international business by itself and it is sanctioned by the state. Business custom which different states created in the trade between one another and is retained by them may differ from that practice.

This customary practice deals with the rules, which have been established and applies only to certain subjects; meanwhile business custom applies to an indeterminate number of subjects, developed mostly by the relevant business sector.

Rules of interpretation may also qualify as indirect contractual stipulations. Their main purpose lies in specifying certain clauses, which are commonly used in business relations and should be interpreted according to clearly defined rules. Probably the most frequently used and best known explanation of how certain trade terms are to be interpreted in international business are the INCOTERMS published and regularly updated by the International Chamber of Commerce in Paris. ${ }^{39}$ These INCOTERMS are interpretations of collateral clauses suggested for use in contracts with foreign business partners. ${ }^{40}$

\subsection{Characteristics of Business Terms and Conditions}

Business terms and conditions are, thus, classified as indirect contractual arrangements. They are not always included in the contract, but more often they are attached to the contract, or they are printed

36 MAREK, K. - ŽVÁČKOVÁ, L.: Obchodní podmínky, obchodní zvyklosti a vykládací pravidla. $1^{\text {st }}$ Edition. Praha : ASPI, Wolters Kluwer, 2008 p. 15.

37 Available at: <https://iccwbo.org/resources-for-business/incoterms-rules/incoterms-rules-2010> (accessed on 5th November 2018)

38 Provision $\$ 558$ of Law No. 89/2012 Coll. Civil Code.

39 Another set of frequently used terms in international trade are payment clauses such as COD ("cash on delivery"), CEL ("cash before delivery"), D/P ("documents against payment"), or CAD ("cash against documents").

40 CHUAH, J. - CHIN, T.: Law of international trade. $2^{\text {nd. }}$. edition. London: Sweet \& Maxwell, 2001, p. 89. 
on the reverse of the contract. Personally, I consider the second method to be more appropriate. In practice, people preparing an international commercial contract can avoid problems if they do not abstain from referring to these terms. Reference to INCOTERMS is considered to be a proper proceeding because in the absence of an indication of the year of their publication, it would not be easy to determine which business conditions had actually been used in a contractual relationship. ${ }^{41}$

Another characteristic of business terms and conditions is that they are considered to be subsidiary contractual arrangements. Business terms and conditions should address issues of a specific obligation in a contractual relationship which is not explicitly referred to in the contract. Only the essential elements of the contract are in such a case expressly stated in the contract itself, whereas other rights and obligations, respectively technical and quality requirements are specified in the terms and conditions. (e.g. transport modalities and passing of the risk of loss during transport).

Other features of business terms and conditions include abstractness. Business terms and conditions are more abstract than stipulations in individually negotiated contracts. Pre-formulated business terms and conditions are basically generalized contractual templates that complement the contract and rationalize and typify in particular frequently repeated and bulk deals. ${ }^{42}$ In the contract itself only the type, amount and little more must be specified.

Other attributes of business terms are their unambiguousness and comprehensiveness. However, these features are rather requirements than characteristics. In practice, it is undesirable for general commercial terms to contain unclear arrangements or formulations that could be ambiguous. However, as mentioned above, it will rather be a requirement for eliminating contradictions and avoiding disputes when it comes to mind.

Contractual partners should be fully aware of the terms and conditions incorporated in the contract and should be alerted by their existence since the consent of the contractual partners to their application and wording is required. Such an agreement may in theory be reached orally, because the conclusion of a contract is not dependent on a written form. It should also be possible to make a verbal reference to the content in business terms. Such a procedure cannot be recommended, however, because, it would then be very difficult to prove that consent.

Finally the compliance with mandatory law may be identified as another characteristic feature of business terms. Business terms that would be inconsistent with mandatory standards of the applicable law are absolutely invalid or ineffective. General terms and conditions are also used in domestic relations, but their main purpose is to meet the needs of international trade.

\subsection{Terminological Differences in International Context}

Further, it is necessary to examine the role of individual contractual terms and their concepts in the context of general commercial terms. Terms and conditions are part of multilateral legal acts and as such their contents are either already closed or should be closed. It is necessary to make a distinction between contract terms and unilateral declarations on the one hand, and legal relationships arising without contract by regulations of public law on the other. Thus, provisions or clauses affecting the creation of a contract which are not a part of its content must be considered, which means that they govern the prerequisites for the conclusion of the contract and the moment of its conclusion.

41 INCOTERMS are overhauled by the ICC every ten years: 1990. 2000, 2010 etc.

42 HAJN, P. - BEJČEK, J.: Jak uzavírat obchodní smlouvy. $2^{\text {nd }}$ Edition. Praha: Linde, 2003, p. 133. 
The concept of business terms and conditions is enshrined in the Czech Civil Code in Section $1751 .{ }^{43}$ General terms and conditions are designed for multiple application by the user and are implemented into the contract as conditions which are proposed by one party to the contract, viz the user, and submitted to the other contracting party when entering the negotiations. ${ }^{44}$

It is not decisive whether general commercial terms of business form a separate part of the contract or whether the contract is incorporated into the document itself. They are often referred to internationally as general terms of the contract, general commercial terms, general sales conditions, or standard form contracts. The lay public also uses the term "small letter prints". This denomination is, however, very inaccurate, because not everything written in small print is a general commercial term and vice versa, not any term of expression that is printed in small types contains general commercial terms. The form in which the general commercial terms are implemented is not primarily decisive, but their content is. Where general terms and conditions are used, there is a generalized abstract part incorporated in the contract. From a practical point of view, this part is standardized and provides important passages of the contract, since it contains specific rules on liability, confidentiality, commercial representation of the framework cooperation etc.

These clauses are intended for a larger group of contracts and also formulated for this group. ${ }^{45}$ For the assessment, whether they qualify as general commercial terms or not it is neither important that they are an integrated part of the contract or added as an annex to the contract, nor what content they have or how they are drawn up in a specific form.

\subsection{Defining the types of business conditions}

In defining the types of business conditions, Czech law provides Section 237 (1) of the Commercial Code $^{46}$ which recognizes, on the one hand, general commercial terms drawn up by professional or charitable organizations and other manifestations of contractual conditions, on the other, for example stipulations inserted by one of the contracting parties.

The Civil Code deals with general commercial terms in Section 1752, although it retains the categorical classification in terms of the entities by which they are made. Furthermore, the Civil Code does not expressly specify which professional or interest organizations should have the right to draw up business conditions. It is possible that for one business area different organizations may create different general commercial terms in regard to the involved type of contracts.

The distinction between general terms and conditions and other business conditions was linked to the presumption of their general knowledge and acceptance. The terminological link, viz "general terms and conditions", is often considered to be in compliance with the established terminology. Often the notions "business terms and conditions" and "general commercial terms" are understood synonymously. For the purposes of this study and with regard to the practice of international business and to the characteristics of the business terms the notion "General Terms and Conditions", abbr. "GTC" shall be used for standardized instruments prepared for use by parties to an international contract.

43 Act No. 89/2012 Coll., Civil Code, until lately named as New Civil Code for its novelty.

44 ULMER, P. - BRANDNER, H. E. - HENSEN, H. D.: AGB-Recht. Kommentar zu den Paragrafen 305-310 BGB und zum Unterlassungsklagengesetz. 12 $2^{\text {th }}$ Edition. Köln: Dr. Otto Schmidt, 2016, p. 2.

45 STAUDINGER, J.: Kommentar zum Bürgerlichen Gesetzbuch, Buch 2, Recht der Schuldverhältnisse, Paragrafen $305-$ 310. Berlin: Sellier - de Gruyter, 2006, Marg.no. 21.

46 Act No. 513/1991 Coll., which replaced the Code of International Private Law; Act No. 89/2012 Coll. Civil Code. 
Unification of model conditions may be the result of an international treaty, some of which are developed by international organizations, whether governmental or non-governmental, that are involved in the development of the logistics of international trade. The acceptance and use of these business conditions have grown gradually with the importance of export trade.

Of greater importance have become a number of UNCITRAL-Documents. In 1966, the UN decided to take part in the progressive harmonization of international trade law and constituted the UN Commission on International Trade Law, abbr. UNCITRAL. This Commission focuses on the preparation and negotiation of multilateral international treaties, the negotiation and presentation of unifying model regulations, legislative recommendations, and other activities. ${ }^{47}$

Another set of Documents and principles concerning international trade and commerce has been elaborated by the International Chamber of Commerce, abbr. ICC. The ICC is a global business organization with representations of businesses from the entire world. Among the ICC-documents with the greatest relevance are the INCOTERMS. Other important documents issued by the ICC are The Uniform Custom and Practice for Documentary Credits, The Rules for the ICC Court of Arbitration, Uniform Rules for Contract Guarantees, and the Force Majeure and Hardship Clauses. ${ }^{48}$

In the year 1964 the diplomatic conference in La Hague approved the Uniform Laws on International Sales, viz two "unification laws", one of which was focussing on the substantive law of international sale of goods whereas the second focused on "formation" of contracts for international sale of goods. The (Hague) Uniform Laws on International Sales had little success however, since they were found to be too complicated. Cases applying the uniform law have been reported more or less only from German and Italian courts, whereas English Lawyers paid no attention to The Hague Sales Law, since the application of the English Uniform Laws on International Sales Act 1967 depended on an opting in by the parties to an international contract for the sale of goods. ${ }^{49}$

Different model contracts and general commercial terms are also used by parties concluding international contracts in the construction sector. ${ }^{50} \mathrm{~A}$ number of model conditions for international business relations are mainly used in the Anglo-American environment, for example the "Conditions of Contract for Works of Civil Engineering Construction" or the "General Conditions of Contract for Civil Works". ${ }^{51}$

\subsection{Business terms, different contractual arrangements, interpretation rules, and their relationship}

The relationship between general terms and conditions on the one hand and individual contractual arrangements on the other are dealt with by the Czech Civil Code which indicates preference for individually agreed contractual arrangements. Thus, if in practice a situation arises where general

47 Available at: <http://www.uncitral.org/> (accessed on $5^{\text {th }}$ November 2018).

48 Available at: $<$ https://iccwbo.org/publication/icc-force-majeure-clause-2003icc-hardship-clause-2003/ $>$ (accessed on $5^{\text {th }}$ November 2018).

49 SCHMITTHOFF, C.: Schmitthoff's export trade. The law and practice of international trade. London: STEVENS \& SONS, 1986, p. 60.

50 In the Czech Republic for example General Terms and Conditions for the construction, issued by S.I.A. Czech Republic Construction Council and Economic Chamber of the Czech Republic under the auspices of the Ministry of Industry and Trade of the Czech Republic and the Ministry for Regional Development of the Czech Republic, compare further: $<$ http://fidic.org/book-product-type/works-civil-engineering-construction> (accessed on $5^{\text {th }}$ November 2018).

51 As developed by the UNDP (United Nations Development Program). 
terms of business would govern a particular matter differently from the individually negotiated contract, the latter will prevail in accordance with Section 1751 (1) of the Civil Code, against any contradictory provisions of the business conditions.

The Czech Civil Code also provides an answer to the question how a possible conflict between business conditions and differing contractual arrangements should be resolved. In practice, such a case could occur if, for example, the contract will set a different clause for the rules of delivery in compliance with the INCOTERMS 2010 rather than with "private" general business conditions forming the basis of a contract. The Czech Civil Code in Section 1754 (1) provides that where the parties apply a clause which is used in the contract, it is considered that they intended to produce the legal effects provided for by the rules of interpretation to which they have resorted in the contract, or those rules of interpretation, which are usually applied in view of the nature of the contract. Under paragraph 2, if one party of the contract is not an entrepreneur, the clause can be invoked if there is evidence that this meaning must have been known by the other party.

\subsection{Terms of business in other legislation and set of rules}

The Civil Code is not the only legal regulation in Czech law which refers to general terms and conditions and their use. Other laws regulating business conditions, their elaboration and application include, for example, Act No. 363/1999 Coll., On Insurance, as amended, Act No. 21/1992 Coll., On Banks, as amended, Act no. 137/2006 Coll., On Public Procurement, as amended, Act No. 458/2000 Coll., On Business Conditions and Performance of State Administration in the Energy Sectors and on the Amendment to Certain Acts (Energy Act), as amended, and others laws.

Significant attention is also paid to rules in general terms and conditions for the sale of goods in international trade law. The focus of the international instruments in the field of sale of goods lies primarily on business conditions and model contracts created by specialized organizations.

These terms and conditions are binding on the parties if they have negotiated their application in the contract. For contracts for the supply of capital goods in the international trade, it is typical that their realization takes place through several distinct types of transactions. Generally, it is a combination of the supplies of goods and services and the execution of certain works. Another characteristic feature of these types of contracts is their technological complexity and financial difficulty. Investors are often states, represented by their authorities or specialized international corporations acting as suppliers. ${ }^{52}$

As regards the law of conflict of laws, there are several options for the choice of the applicable law in these contracts, of which the most ideal appears to be the inclusion of a choice of law rule by the parties in the contract itself. However, as stated in specialized publications, ${ }^{53}$ there exist in many countries appropriate regulations for certain national and international business contracts such as model business conditions and sample contracts which the parties may adopt as a basis for their agreements. These rules on the procurement in the public construction sector are used in the

52 The World Bank. Procurement for Projects and Programs. Available at: <http://web.worldbank.org/WBSITE/EXTERNAL/PROJECTS/PROCUREMENT/0, contentMDK:20060840 pagePK:84269 piPK:60001558 theSitePK:84266,00. html $>$ (accessed on $5^{\text {th }}$ November 2018).

53 KUČERA, Z. - PAUKNEROVÁ, M. - RƯŽIČKA, K. et al.: Právo mezinárodního obchodu. Plzeň: Aleš Čeněk, 2008, p. 285 
Federal Republic of Germany. However, in respect of party autonomy, they are not automatically applied but dependent on parties' consent.

In practice a big number of International Business Conditions has been created by governmental and non-governmental organizations. These contracting regulations generally also contain specific provisions on the determination of the applicable law. For example, Article 5 of the Model Turkey Contract for Major Projects ${ }^{54}$ provides that the applicable law is the law of the State into which the investment unit is supplied unless otherwise agreed by the parties.

It is also appropriate to provide a demonstration of commercial terms and model contracts created by governmental and non-governmental international organizations in the field of international supply of goods, including Standard Terms and Conditions of the United Nations Economic Commission for Europe, the World Bank publication, i.e. standardized tender supplies of investment units. The European Development Fund and its general rules and general conditions for work contracts, supply contracts, and service contracts, and contracts funded by the European Development Fund. Business Terms of the International Federation of Consulting Engineers, abbr. FIDIC, and the Model Contracts and Clauses on Drafting and Negotiating Commercial Contracts of the International Chamber of Commerce in Paris.

The importance of general terms and conditions in international trade and international sales contracts is evident not only in the day-to-day legal practice but also in the event of disputes arising in the performance of contracts with an international element. It is clear that both, practice and theory, consider the inclusion of choice-of-law arrangements, of clauses on the international jurisdiction of the court or arbitration clauses, as pillars of treaties that initiate export or import issues. Also clauses on the extent, limitation, or distribution of liability in case of a breach of contracts can be suggested in the form of general commercial terms and can be very helpful for contracting parties who are not familiar with foreign contract practices as well as foreign law and legal terminology.

In practice, not only the assumption of the validity of general commercial terms, but also their interaction with the relevant legislation plays an important role for negotiating and concluding international business contracts. The general problem of international trade is, that it is regulated not only by the provisions of national rules on Private International Law, by international conventions, substantive national contract laws and general terms and conditions for commercial contracts. In recent years a great number of regulations and directives concerning the rules of conflict of laws and the specific features of certain contracts have been enacted by the EU thereby adding complexity and circumstantiality to the already complicated situation. With the implementation and existence of general commercial terms are related questions of their interaction with the emergence of a contract law relationship, the impact on its existence or the avoidance of its occurrence and, of course, the question related to the assessment of the situation in which the general commercial terms can become part of the treaties themselves.

The peculiar problems resulting from the specific situations associated with the application of general commercial terms as well as with the established business practice and the need for a specific reference to the implementation of the general trading conditions are of major concern for modern trade and commerce. Together with the issue of commercial law and other co-occurring phenomena they constitute an important chapter of international business relations. Last but not least, it

54 Publication of International Commission No. 659 E from 2007. Available at: <http://store.iccwbo.org/icc-model-turnkey-contract-for-major-projects/> (accessed on $5^{\text {th }}$ November 2018). 
is also necessary to discuss the possible collision of general commercial terms on which a contract may be based and its solution. The issue of the relevance of general conditions is also related to the manifestations of the parties' intention connected with the conclusion of the contract itself and the creation of its content, which is undoubtedly linked to the control of the scope and impact of the effect of general conditions of trade.

\section{CONCLUSION}

It is clearly evident, therefore, that both the breadth of the problems and their importance for the commercial practice can, in particular, be demonstrated for international trade relations. From the point of view of mutual interaction, it is, of course, necessary to take into account the practical importance of the international harmonization of certain areas of commercial law. In particular, the interaction of the United Nations Convention on Contracts for the International Sale of Goods (abbr. CISG) with the national regulations of the national laws of the 89 States which have ratified the CISG so far, among them the Czech Republic, The term "general commercial terms", is not defined by the CISG.

Within individual national regulations, we encounter different definitions of general commercial terms, and in the context of the gaps in international conventions, it is a question of whether national laws can fill these gaps. The issue of general commercial terms is important not only from the point of view of the practical and legal analytical approach but also from the point of view of the economic contribution and importance of this institute. Their application occurs not only in the international sales contract between entrepreneurs but also in the consumer legal relations, viz in relations between businessmen and consumers. Issues related to the application of widely recognized general terms and conditions concern e.g. the various options and ways of payment, the modes of conveyance, the transfer of risks and the limitation or exclusion of liability.

As discussed above, it must be considered that all issues related to the use of general commercial terms cannot be settled by the reference to national legal concepts only, but depend on the compliance with an international and cross-border perception of many legal relationships, since the question of the existence and evaluation of general commercial terms is linked to the approach of the applicable law or the rules of the CISG if the law of a contracting state is involved. ${ }^{55}$ Meanwhile, this international convention has been ratified by virtually all advanced states with the exception of the United Kingdom. ${ }^{56}$

Since 1988, when CISG entered into effect for ten pioneer states, important developments have been launched and numerous adjustments proposed within the activities of international organizations and institutions, such as the Principles for the Use by Parties of UNIDROIT Principles of International Commercial Contracts, the attempt to create a uniform European contract law based

55 On April 11, 1980, the UN Convention on Contracts for the International Sale of Goods was negotiated in Vienna. On behalf of the Czech and Slovak Federative Republic, the Convention was signed in New York on 1 September 1981 and published under No. 160/1991 Coll.

56 Until today the convention has been ratified by almost 90 states. The current number may be checked on the web page of UNCITRAL. United Nations Convention on Contracts for the International Sale of Goods (Vienna, 1980) (CISG). Available at: <http://www.uncitral.org/uncitral/en/uncitral_texts/sale_goods/1980CISG_status.html> (accessed on $5^{\text {th }}$ November 2018). 
on the principles of European Contract Law, abbr. PECL and, most intensively of course, questions connected to the Draft Common Frame of Reference, abbr. DCFR. All these activities are the results of the long-term tendency of harmonizing contract law and of comparative research in various scientific circles and practical committees. Currently the reform process has turned towards common principles rather, than to hard and fast statutory rules of the subject matter. ${ }^{57}$

Modifications aiming at unification and harmonization of laws have brought significant progress within the EU in the area of conflict issues for both contractual and non-contractual obligations. ${ }^{58}$ In connection with this unification trend, the issue of development within the framework of substantive law and the related issues of the preparation of a European Private Code have also continued, however, less intensively as before. Currently, the negative developments in European integration are indicative of stagnation and failure in such endeavours. There is also no talk of codifying European private law in the context of the European Parliament's motions addressed to the European Commission requesting the creation of a European Civil Law. ${ }^{59}$ Thus, even reform projects for a limited field of contract law like the Proposal for a Regulation of the European Parliament and of the Council on a Common European Sales Law ${ }^{60}$ apparently have no chance to be realized within a foreseeable time. The evolution within the European Commission has not only stagnated but has even been interrupted and, in the light of current political developments, has been replaced by a direction beyond the unification framework and strictly limited to harmonization. ${ }^{61}$ In view of these developments, it appears, at least for the moment, inappropriate to rely on the adaptation of questions relating to general commercial terms and standard-form contracts within EU-law and its unifying impact. ${ }^{62}$

\section{Bibliography:}

ADAMS, M.: Ökonomische Begründung des AGB-Gesetzes. In: Betriebs Berater, 1989.

BAUDENBACHER, C.: Ansätze zu einer AGB Kontrolle im schweizerischen Recht. St. Gallen: Wissenschaftlicher Verlag, 1991.

BAUER, W. B.: Der Schutz vor unbilligen Allgemeinen Geschäftsbedingungen (AGB) im schweizerischen Recht. $3^{\text {rd }}$ Edition. Zürich: Schulthess, 1977.

CORDES, A.: Gut behütet über die Weltmeere. In: Frankfurter Allgemeine Sonntagszeitung, 19. 06. 2011.

DiMATTEO, L. - JANSEN, A. - MAGNUS, U. - SCHULZE, R.: International Sales Law. Baden - Baden: Nomos, 2016. 1085 p., ISBN 9783848721993.

57 Compare ZIMMERMANN, R.: Die "Principles of European Contract Law", Teil I. In: Zeitschrift für Europäisches Privatrecht, 1995, No. 4, p. 731; ZIMMERMANN, R.: Konturen des neuen Europäischen Vertragsrechts. In: JuristenZeitung, 50, 1995, no. 10, p. 477.

58 For example, the Council Regulation (EC) No 44/2001 on jurisdiction and the recognition and enforcement of judgments in civil and commercial matters (so called Brussels I Regulation), Council Regulation (EC) No 2201/2003 concerning jurisdiction and the recognition and enforcement of judgments in matrimonial matters and the matters of parental responsibility, repealing Regulation (EC) No 1347/2000 (so called Brussels IIa Regulation), Regulation (EC) No 864/2007 of the European Parliament and of the Council on the law applicable to non-contractual obligations (Rome II) and Regulation (EC) No 593/2008 of the European Parliament and of the Council (Rome I).

59 Official Journal of the European Communities No. C 158/400 and 1994 No. C 205/518.

60 COM/2011/0635 final - 2011/0284 (COD).

61 HESSELINK, M.: How to Opt into the Common European Sales Law? Brief Comments on the Commission's Proposal for a Regulation. In: European Review of Private Law, 20, 2012, No. 1, p. 196.

62 SCHMIDT-KESSEL, M.: Der Vorschlag der Kommission für ein optionales Instrument- ein einheitliches europäisches Kaufrecht? Eine Analyse des Vorschlags der Kommission. München: Sellier European Law Publishers, 2012, p. 1-27. 
FRIER, B. W.: Landlords and Tenants in Imperial Rome. New Jersey: Princeton University Press, 1980. 294 p., ISBN 9780691643083.

GOLDSCHMIDT, L.: Handbuch des Handelsrechts. Bd. 1. Erste Abteilung: Universalgeschichte des Handelsrechts. $3^{\text {rd }}$ Edition. Stuttgart: F. Enke, 1891. 497 p.

HAJN, P. - BEJČEK, J.: Jak uzavírat obchodní smlouvy. 2nd Edition. Praha: Linde, 2003. 284 p., ISBN 8072014153.

HELLWEGE, Ph.: Allgemeine Geschäftsbedingungen, einseitig gestellte Vertragsbedingungen und die allgemeine Rechtsgeschäftslehre. Tübingen: Mohr Siebeck, 2010. 667 p.

HESSELINK, M.: How to Opt into the Common European Sales Law? Brief Comments on the Commissions Proposal for a Regulation. In: European Review of Private Law, 20, 2012, 20, No. 1.

CHUAH, J. - CHIN, T.: Law of international trade. $2^{\text {nd }}$. edition. London: Sweet \& Maxwell, 2001.

KRAMER, E.: Art. 19-22 OR. Allgemeine Bestimmungen. Inhalt des Vertrages. Berner Kommentar. Bern: Stämpfli, 1991. 282 p., ISBN 9783727234149.

KUČERA, Z. - PAUKNEROVÁ, M. - RU゚ŽIČKA, K. et al.: Právo mezinárodního obchodu. Plzeň: Aleš Čeněk, 2008. 407 p., ISBN 9788073801083.

MALACKA, M.: Kolizní metoda v kontextu globalizace a europeizace, Kodifikace obecné části kolizního práva - cesta či omyl? In: Acta Universitatis Brunensis Iuridica, vol. 548, 2016, ISBN 978-80-210-8195-6.

MAREK, K. - ŽVÁČKOVÁ, L.: Obchodní podmínky, obchodní zvyklosti a vykládací pravidla. $1^{\text {st }}$ Edition. Praha: ASPI, Wolters Kluwer, 2008. 296 p., ISBN 9788073573331.

MÜLLER, W. - GRIEBELER, C. - PFEIL, J.: Für eine maßvolle AGB-Kontrolle im unternehmerischen Geschäftsverkehr. In: Betriebs Berater, 2009.

Official Journal of the European Communities No. C 158,400 and 1994 No. C 205/518.

RAISER, L.: Das Recht der Allgemeinen Geschäftsbedingungen. Bad Homburg: Gentner, 1961.

RAMBERG, J.: International commercial transactions. Stockholm: Kluwer Law International, 1998.

RANIERI, F.: Europäisches Obligationenrecht, 3. Edition. Wien: Springer, 2009. 2044 p., ISBN: 9783211893739.

ROZEHNALOVÁ, N.: Právo mezinárodního obchodu. 2nd Edition. Praha: ASPI, 2006. 549 p., ISBN: 9788073575625.

ROZEHNALOVÁ, N.: Standardizované formy uzavírání obchodních smluv v mezinárodním obchodě. Brno: Masarykova univerzita, 1991.

SCHMIDT-KESSEL, M.: Der Vorschlag der Kommission für ein optionales Instrument- ein einheitliches europäisches Kaufrecht? Eine Analyse des Vorschlags der Kommission. München: Sellier European Law Publishers, 2012. 464 p., ISBN 9783866532137.

SCHMITTHOFF, C.: Schmitthoff's export trade. The law and practice of international trade. London: STEVENS \& SONS, 1986. 798p.

STAUDINGER, J.: Kommentar zum Bürgerlichen Gesetzbuch, Buch 2, Recht der Schuldverhältnisse, Paragrafen $305-$ 310. Berlin: Sellier - de Gruyter, 2006. 1236 p., ISBN 9783805910316.

STOFFELS, M. AGB-Recht. 2nd Edition. München: C. H. Beck, 2009. 525 p., ISBN 9783406642609.

ULMER, P. - HENSEN, H. D. - CHRISTENSEN, G. - FUCHS, A. - SCHMIDT, H.: AGB Recht. Kommentar zu den Paragrafen 305-310 BGB und zum Unterlassungsklagensgesetz. 12 ${ }^{\text {th }}$ Edition. Köln: Otto Smidt, 2016, ISBN 9783504451110

ZIMMERMANN, M.: Mezinárodní právo soukromé. Brno: Cs A.S. Právník, 1933.

\section{Internet resources:}

Bundesnotarkammer, Bundesrechtsanwaltskammer U.A. Law - Made in Germany, 2012. Available at: <http://www. lawmadeingermany.de/Law-Made_in_Germany.pdf> (accessed on $5^{\text {th }}$ November 2018).

Management Circle. Schweizer Recht im Anlagenbau, 2017. Available at : <http://www.managementcircle.de/seminar/schweizer-recht-im-anlagenbau.html> (accessed on $5^{\text {th }}$ November 2018). 
The Law Society of England and Wales. England and Wales: The jurisdiction of choice [online]. eversheds-sutherland. com, 2007. Available at: <http://www.eversheds-sutherland.com/documents/LawSocietyEnglandAndWalesJurisdictionOfChoice.pdf $>$ (accessed on $5^{\text {th }}$ November 2018).

The World Bank. Procurement for Projects and Programs. Available at: <http://web.worldbank.org/WBSITE/EXTERNAL/PROJECTS/PROCUREMENT/0,contentMDK:20060840 pagePK:84269 piPK:60001558 theSite PK:84266,00.html $>$ (accessed on $5^{\text {th }}$ November 2018).

UNCITRAL. United Nations Convention on Contracts for the International Sale of Goods (Vienna, 1980) (CISG), 2017. Available at : <http://www.uncitral.org/uncitral/en/uncitral_texts/sale_goods/1980cisg.html> (accessed on $5^{\text {th }}$ November 2018).

Publication of the International Chamber of Commerce No. 659 E from 2007 Available at: <http://store.iccwbo.org/ icc-model-turnkey-contract-for-major-projects $>$ (accessed on $5^{\text {th }}$ November 2018).

\section{Legislation}

Act No. 89/2012 Coll., the Civil Code, as amended

Act No. 513/1991 Coll., Commercial Code, as amended

\section{Contact information:}

JUDr. Mag. iur. Michal Malacka, PhD., MBA

michal.malacka@upol.cz

Univerzita Palackého

Právnická fakulta

Tř. 17. Listopadu 8

Olomouc 77900

Czech Republic 